\title{
Effect of theophylline and enprofylline on bronchial hyperresponsiveness
}

\author{
G H KOËTER, J KRAAN, M BOORSMA, J H G JONKMAN, TH W VAN DER MARK \\ From the Department of Pulmonology and Lung Function, University Hospital, Groningen; Pharma Bio \\ Research, Assen; and Astra Pharmaceutica, Rijswijk, The Netherlands
}

\begin{abstract}
The effect of increasing intravenous doses of theophylline and enprofylline, a new xanthine derivative, on bronchial responsiveness to methacholine was studied in eight asthmatic patients. Methacholine provocations were carried out on three days before and after increasing doses of theophylline, enprofylline, and placebo, a double blind study design being used. Methacholine responsiveness was determined as the provocative concentration of methacholine causing a fall of $20 \%$ in $\mathrm{FEV}_{1}\left(\mathrm{PC}_{20}\right)$. The patients were characterised pharmacokinetically before the main study to provide an individual dosage scheme for each patient that would provide rapid steady state plasma concentration plateaus of 5,10 , and $15 \mathrm{mg} / \mathrm{l}$ for theophylline and $1.25,2.5$, and $3.75 \mathrm{mg} / \mathrm{l}$ for enprofylline. Dose increments in the main study were given at 90 minute intervals. FEV small progressive decrease after placebo; it remained high in relation to placebo after both drugs and this effect was dose related. Methacholine $\mathrm{PC}_{20}$ values decreased after placebo; mean values were higher after theophylline and enprofylline than after placebo (maximum difference 2.0 and 1.7 doubling doses of methacholine); the effect of both drugs was dose related. Thus enprofylline an $\$$ theophylline when given intravenously cause a small dose related increase in $\mathrm{FEV}_{1}$ and methacholime $\mathrm{PC}_{20}$ when compared with placebo.
\end{abstract}

Theophylline is widely used as maintenance treatment for patients with moderately severe asthma. ${ }^{1}$ In addition to causing dose related bronchodilatation, ${ }^{2}$ theophylline provides some protection against the effects of constrictor agents such as histamine and methacholine. ${ }^{3-7}$ Enprofylline, a recently developed xanthine derivative, is three to five times more potent as a bronchodilator than theophylline, ${ }^{89}$ and might have advantages over theophylline if central nervous system side effects are less. ${ }^{10}$

In the present study increasing doses of enprofylline and theophylline were given intravenously to patients with asthma to examine the protective effect of theophylline and enprofylline on bronchoconstriction induced by inhaled methacholine and to relate this to the plasma concentrations of the two drugs. Before the study the pharmacokinetics of both drugs were determined for each patient so that individualised drug doses could be given and plasma concentrations held within narrow limits.

Address for reprint requests: Dr G H Koëter, Department of Pulmonology, State University Hospital, 9713 EZ Groningen, The Netherlands.

Accepted 20 July 1989

\section{Methods}

PATIENTS

Eight asthmatic men (mean age 29, range 23-34 years) gave their written, informed consent to participate in the study. The clinical characteristics of each patient are shown in table 1. Patients had to show an increase in forced expiratory volume in one second $\left(\mathrm{FEV}_{1}\right)$ of at least $15 \%$ after $200 \mu \mathrm{g}$ terbutaline. All patients had increased bronchial responsiveness to methacholine (a $\delta$ provocation concentration causing a fall of $20 \%$ in $₹$ FEV $_{1}\left(\mathrm{PC}_{20}\right)$ below $4 \mathrm{mg} / \mathrm{l}$; see "Provocation tests" 은 below).

Asthma was well controlled in all subjects by a small $\frac{T}{O}$ dose of an inhaled bronchodilator or a prophylactic drug (sodium cromoglycate or an inhaled cortico- of steroid) or both. Two patients took theophylline as $N$ maintenance treatment; this was withheld for at least one week before each study day. No patient was receiving regular oral steroids.

PROVOCATION TESTS

Slow inspiratory vital capacity (VC) and $\mathrm{FEV}_{1}$ were measured with a water sealed spirometer. Increasing $\bar{O}$ concentrations of methacholine were inhaled from a 
Table 1 Clinical data on the patients

\begin{tabular}{|c|c|c|c|c|c|c|}
\hline Patient No & Age (y) & $V C(l)$ & $F E V_{l}(l)$ & $F E V_{1}(\%$ pred $)$ & $\begin{array}{l}\% \text { increase above initial } \\
F E V, \text { after terbutaline }\end{array}$ & $\begin{array}{l}\text { Methacholine } \\
P C_{30}(\mathrm{mg} / \mathrm{ml})\end{array}$ \\
\hline $\begin{array}{l}1 \\
2 \\
3 \\
4 \\
5 \\
6 \\
7 \\
8\end{array}$ & $\begin{array}{l}34 \\
29 \\
24 \\
32 \\
23 \\
29 \\
25 \\
33\end{array}$ & $\begin{array}{l}5 \cdot 40 \\
5 \cdot 50 \\
5 \cdot 50 \\
4.90 \\
5 \cdot 40 \\
5 \cdot 30 \\
6 \cdot 30 \\
3.70\end{array}$ & $\begin{array}{l}3 \cdot 25 \\
3 \cdot 00 \\
3 \cdot 40 \\
2 \cdot 10 \\
3 \cdot 60 \\
3 \cdot 25 \\
4 \cdot 30 \\
2 \cdot 20\end{array}$ & $\begin{array}{l}71 \\
66 \\
71 \\
53 \\
71 \\
77 \\
89 \\
62\end{array}$ & $\begin{array}{l}18 \\
40 \\
25 \\
18 \\
19 \\
21 \\
16 \\
37\end{array}$ & $\begin{array}{l}0.78 \\
0.10 \\
0.24 \\
0.10 \\
1.07 \\
1.41 \\
0.18 \\
0.03\end{array}$ \\
\hline $\begin{array}{l}\text { Mean } \\
\text { SD }\end{array}$ & 29 & $\begin{array}{l}5 \cdot 25 \\
0 \cdot 74\end{array}$ & $\begin{array}{l}3 \cdot 14 \\
0 \cdot 72\end{array}$ & $\begin{array}{l}70 \\
11\end{array}$ & $\begin{array}{r}24 \\
9\end{array}$ & $0.24 \dagger$ \\
\hline
\end{tabular}

*The terbutaline effect was tested on a separate study day. The inhaled dose was $0.50 \mathrm{mg}$ (two puffs).

tGeometric mean value.

VC-vital capacity; $\mathrm{FEV}_{1}$-forced expiratory volume in one second; $\mathrm{PC}_{20}$ - provocation concentration causing a $20 \%$ fall in $\mathrm{FEV}$.

Wiesbadener Doppelspray (Wiesbadener InhalatorVertrieb, Wiesbaden, West Germany) with an airflow of $81 / \mathrm{min}$. The output of the nebuliser was $0 \cdot 12$ (SEM $0.02) \mathrm{ml} / \mathrm{min}$. The aerosols were inhaled during tidal breathing, with the patient wearing a nose clip. Doubling concentrations of methacholine from 0.032 to $8 \mathrm{mg} / \mathrm{ml}$ were inhaled for two minutes at five minute intervals until the FEV, had fallen by $20 \%$ from the $\mathrm{FEV}_{1}$ after a control inhalation of saline $0 \cdot 9 \%$.

Log dose methacholine was plotted against $\mathrm{FEV}_{\text {, }}$ and the provocation concentration of methacholine required to produce a fall in $\mathrm{FEV}$, of $20 \%$ measured by interpolation."

The theophylline and enprofylline concentrations in plasma were determined by a high pressure liquid chromatography method. ${ }^{1213}$

\section{STUDY DESIGN}

Pharmacokinetic indices for each individual were measured on separate days after an intravenous bolus of $2 \mathrm{mg} / \mathrm{kg}$ theophylline and $1 \mathrm{mg} / \mathrm{kg}$ enprofylline. Total body clearance, volume of distribution at steady state, and volume of the central compartment were calculated from the drug plasma time-concentration curve.

The challenge tests were carried out on three days, before and after theophylline, enprofylline, and placebo. After baseline lung function measurements an inhalation provocation test with methacholine was carried out. Baseline $\mathrm{FEV}_{1}$ values on the three study days had to be within $10 \%$ of the mean value for the three days, and the initial methacholine $\mathrm{PC}_{20}$ values had to be within one dose step on the three days. After the baseline measurement an infusion was given over a total period of 270 minutes. An intravenous bolus dose of drug was given initially over three minutes to raise the plasma xanthine concentration to the first plateau level. The bolus dose was immediately followed by an exponentially decreasing dose by infusion during the succeeding 87 minutes. The procedure was repeated at
90 and 180 minutes $^{14}$ in an attempt to achieve the three successive concentration plateaus with increasing doses of drug. The plasma concentrations aimed for were $5 \cdot 0,10 \cdot 0$, and $15.0 \mathrm{mg} / \mathrm{l}$ for theophylline and 1.25 , 2.50 , and $3.75 \mathrm{mg} / \mathrm{l}$ for enprofylline. The drug doses needed to achieve these goals were calculated from the pharmacokinetic measurements for all the subjects and prepared by the pharmacist in individual bottles for each subject to ensure that the study was blind for both the investigators and the patients.

The inhalation provocation with methacholine was repeated on three occasions for each drug 60 minutes after the start of each infusion at an increased drug concentration. The patients were not allowed to have beverages containing xanthine during the study days.

\section{STATISTICAL ANALYSIS}

Methacholine $\mathrm{PC}_{20}$ values were $\log$ transformed. The response to theophylline and enprofylline was expressed as the difference between $\log \mathrm{PC}_{20}$ on the active treatment days and the placebo days. Change in $\mathrm{FEV}_{1}$ values was expressed as a percentage of the baseline value on each day. With these as dependent variables, analysis of variance was carried out with treatment and dosage step as independent variables, ${ }^{15}$ followed by Duncan's multiple range test to establish differences between groups. Linear regression analysis was used to relate plasma xanthine concentration to change in $\mathrm{FEV}_{1}$ and methacholine $\mathrm{PC}_{20}$ (baseline measurements being excluded).

\section{Results}

THEOPHYLLINE AND ENPROFYLLINE PLASMA CONCENTRATIONS

Plasma concentration remained stable during the continuous infusion period after each increment. The mean plasma concentrations (table 2) deviated little from the concentrations we aimed at (theophylline 5·3, $10 \cdot 2,15 \mathrm{mg} / \mathrm{l}$; enprofylline $1 \cdot 2,2 \cdot 4,3 \cdot 7 \mathrm{mg} / \mathrm{l})$. 
Table 2 Plasma xanthine concentration at measurement of methacholine $P C_{20}$

\begin{tabular}{|c|c|c|c|c|c|c|}
\hline \multirow{3}{*}{$\begin{array}{l}\text { Patient } \\
\text { No }\end{array}$} & \multicolumn{3}{|c|}{ Theophylline (mg/l) } & \multicolumn{3}{|c|}{ Enprofylline (mg/l) } \\
\hline & \multicolumn{3}{|c|}{ Dose step } & \multicolumn{3}{|c|}{ Dose step } \\
\hline & $l$ & 2 & 3 & 1 & 2 & 3 \\
\hline $\begin{array}{l}1 \\
2 \\
3 \\
4 \\
5 \\
6 \\
7 \\
8\end{array}$ & $\begin{array}{l}5 \cdot 7 \\
5 \cdot 5 \\
5 \cdot 1 \\
5 \cdot 7 \\
5 \cdot 3 \\
5 \cdot 0 \\
4 \cdot 5 \\
5 \cdot 3\end{array}$ & $\begin{array}{r}10.4 \\
11.0 \\
10.8 \\
10.1 \\
10.7 \\
9.2 \\
9.0 \\
10.4\end{array}$ & $\begin{array}{l}16.5 \\
15.6 \\
14.7 \\
14.2 \\
15.9 \\
14.0 \\
13.2 \\
15.6\end{array}$ & $\begin{array}{l}1.3 \\
1.5 \\
1.3 \\
1.4 \\
1.1 \\
1.0 \\
1.1 \\
1.0\end{array}$ & $\begin{array}{l}2.6 \\
3.1 \\
2.8 \\
2.6 \\
2.4 \\
2.3 \\
2.3 \\
1.5\end{array}$ & $\begin{array}{l}4 \cdot 1 \\
5 \cdot 1 \\
4 \cdot 2 \\
3 \cdot 9 \\
3 \cdot 5 \\
3 \cdot 5 \\
3 \cdot 6 \\
2 \cdot 0\end{array}$ \\
\hline $\begin{array}{l}\text { Mean } \\
\text { SD }\end{array}$ & $\begin{array}{l}5 \cdot 3 \\
0 \cdot 4\end{array}$ & $\begin{array}{r}10 \cdot 2 \\
0.7\end{array}$ & $\begin{array}{r}15 \cdot 0 \\
1 \cdot 1\end{array}$ & $\begin{array}{l}1.2 \\
0.2\end{array}$ & $\begin{array}{l}2.4 \\
0.5\end{array}$ & $\begin{array}{l}3.7 \\
0.9\end{array}$ \\
\hline
\end{tabular}

$\mathrm{PC}_{20}$ : see table 1 .

CHANGE IN FEV 1 AND METHACHOLINE PC $_{20}$ Mean baseline values of $F E V_{1}$ and methacholine $P_{20}$ on the three study days did not differ significantly (table 3). Mean change in $\mathrm{FEV}_{1}$ and $\mathrm{PC}_{20}$ from baseline after increasing dosages of active drug and placebo are shown in figures 1 and 2 .

\section{Placebo}

After placebo $\mathrm{FEV}_{1}$ decreased gradually and nonsignificantly from $68 \%$ predicted before methacholine challenge to $58 \%$ before the fourth challenge. Geometric mean methacholine $\mathrm{PC}_{20}$ decreased from $0.25 \mathrm{mg} / 1$ to $0.10 \mathrm{mg} / \mathrm{l}$ after the fourth challenge $(\mathrm{p}<0.01)$.

\section{Theophylline and enprofylline}

There was a dose related effect of both drugs on FEV by comparison with the change after placebo (analysis of variance, $p<0.01$ ). There was a significant relation between the increasing $\mathrm{FEV}_{1}$ and the increasing plasma concentrations for both drugs $(r=0.57$ for theophylline and 0.46 for enprofylline: $p<0.01$ ). The

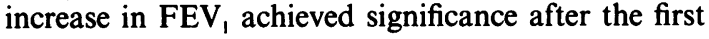

dose increment for theophylline $(p<0.05)$ and after the second for enprofylline $(p<0 \cdot 01)$.

Methacholine $\mathrm{PC}_{20}$ differed progressively from the values seen after placebo with increasing plasma concentrations of theophylline and enprofylline (analysis of variance, $\mathrm{p}<0.05$ ), a significant difference being apparent at the lowest doses (theophylline $5.0 \mathrm{mg} / \mathrm{l}, \mathrm{p}<0.01$; enprofylline $1.2 \mathrm{mg} / \mathrm{l}$ : $\mathrm{p}<0.05)$. Change in methacholine $\mathrm{PC}_{20}$ was related to plasma drug concentration $(r=0.46$ for theophylline and 0.35 for enprofylline: $p<0.05$ for both).

There were no significant differences between the effects of theophylline and enprofylline on $\mathrm{FEV}_{1}$ or methacholine $\mathrm{PC}_{20}$ at any of the three dose increments.

\section{SIDE EFFECTS}

Slight to moderate headache and nausea were noticed by three patients with the highest dose of theophylline and headache by three patients with the highest dose of enprofylline. One patient had a slight headache during the placebo treatment day.

\section{Discussion}

There was a progressive decline in $\mathrm{FEV}_{1}$ and methacholine $\mathrm{PC}_{20}$ after repeated methacholine challenges on the placebo day. The likely explanation for this decline is a cumulative bronchoconstrictor effect of methacholine, the interval between the challenges probably being too short for complete recovery. ${ }^{16}$ Consequently the present study cannot determine the maximal achievable bronchodilatation in these patients or the xanthine plasma concentration at which this occurs. Comparison of drug and placebo, however, in terms of change in $\mathrm{FEV}_{1}$ and methacholine $\mathrm{PC}_{20}$ provides a measure of xanthine induced protection, and the dose dependence of this effect can be assessed. Theophylline and enprofylline caused a dose related improvement in $\mathrm{FEV}_{1}$ and methacholine $\mathrm{PC}_{20}$ by comparison with placebo, significant

Table 3 Effect of increasing doses of theophylline and enprofylline on $F E V_{1}$ (mean (SD)) and methacholine $P C_{20}(g e o m e t r i c$ mean with geometric range of SEM in parentheses)

\begin{tabular}{|c|c|c|c|c|c|c|}
\hline \multirow[b]{2}{*}{$\begin{array}{l}\text { Xanthine } \\
\text { plasma level }\end{array}$} & \multicolumn{2}{|l|}{ Saline } & \multicolumn{2}{|c|}{ Theophylline } & \multicolumn{2}{|c|}{ Enprofylline } \\
\hline & $\begin{array}{l}\text { FEV } \\
\text { (\%pred) }\end{array}$ & $\begin{array}{l}P C_{20} \\
(\mathrm{mg} / \mathrm{ml})\end{array}$ & $\begin{array}{l}\text { FEV } \\
\text { (\%pred) }\end{array}$ & $\begin{array}{l}P C_{20} \\
(\mathrm{mg} / \mathrm{ml})\end{array}$ & $\begin{array}{l}F E V_{1} \\
\text { (\%pred) }\end{array}$ & $\begin{array}{l}P C_{20} \\
(\mathrm{mg} / \mathrm{ml})\end{array}$ \\
\hline 0 & $\begin{array}{l}0.68 \\
(0.04)\end{array}$ & $\begin{array}{l}0.25 \\
(0.15-0.40)\end{array}$ & $\begin{array}{l}0.70 \\
(0.04)\end{array}$ & $\begin{array}{l}0.21 \\
(0 \cdot 13-0.33)\end{array}$ & $\begin{array}{l}0.71 \\
(0.05)\end{array}$ & $\begin{array}{l}0.21 \\
(0.15-0.30)\end{array}$ \\
\hline 1 & $\begin{array}{l}(0.05) \\
0.65 \\
(0.04)\end{array}$ & $\begin{array}{l}0 \cdot 20 \\
(0 \cdot 14-0.31)\end{array}$ & $\begin{array}{l}0.74 \\
(0.03)\end{array}$ & $\begin{array}{l}0.27 \\
(0.19-0.39)\end{array}$ & $\begin{array}{l}0.73 \\
(0.04)\end{array}$ & $\begin{array}{l}0.30 \\
(0.21-0.44)\end{array}$ \\
\hline 2 & 0.64 & $\begin{array}{l}0.12 \\
(0.07-0.21)\end{array}$ & $\begin{array}{l}0.75 \\
(0.03)\end{array}$ & $\begin{array}{l}0.35 \\
(0.23-0.51)\end{array}$ & $\begin{array}{l}0.76 \\
(0.04)\end{array}$ & $\begin{array}{l}0.34 \\
(0.22-0.52)\end{array}$ \\
\hline 3 & $\begin{array}{l}0.58 \\
(0.04)\end{array}$ & $\begin{array}{l}0 \cdot 10 \\
(0 \cdot 06-0 \cdot 17)\end{array}$ & $\begin{array}{l}0.75 \\
(0.03)\end{array}$ & $\begin{array}{l}0.32 \\
(0.23-0.46)\end{array}$ & $\begin{array}{l}0.78 \\
(0.05)\end{array}$ & $\begin{array}{l}0.28 \\
(0.19-0.41)\end{array}$ \\
\hline
\end{tabular}

Abbreviations as in table 1 . 


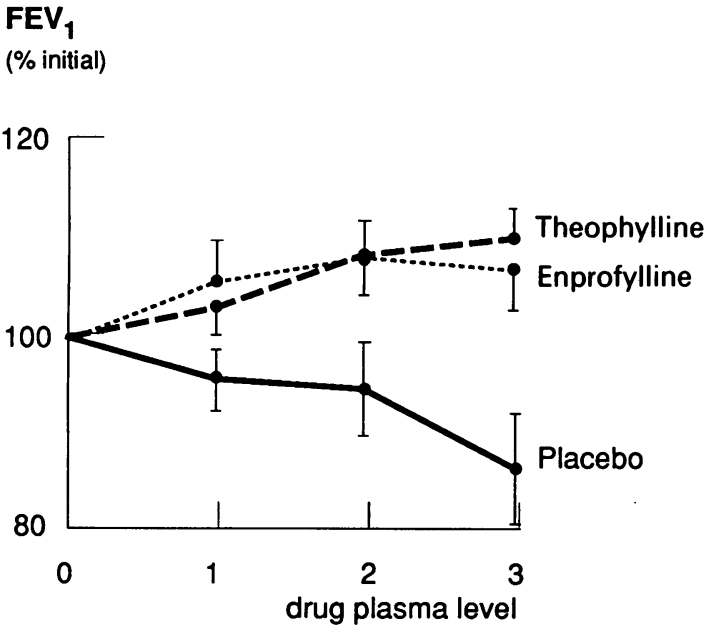

Fig 1 Effect of increasing theophylline and enprofylline plasma concentrations (by comparison with placebo) on $F E V_{1}$, expressed as the percentage change from baseline. The bars indicate standard errors. The drug plasma

concentrations 1,2 , and 3 correspond to $5 \cdot 3,10 \cdot 2$, and $15.0 \mathrm{mg} / \mathrm{l}$ for theophylline and $1 \cdot 2,2 \cdot 4$, and $3 \cdot 7 \mathrm{mg} / \mathrm{l}$ for enprofylline.

differences being seen with relatively low plasma concentrations of both drugs.

Several studies have shown a moderate protective effect of theophylline against histamine ${ }^{3-7}$ and metha-

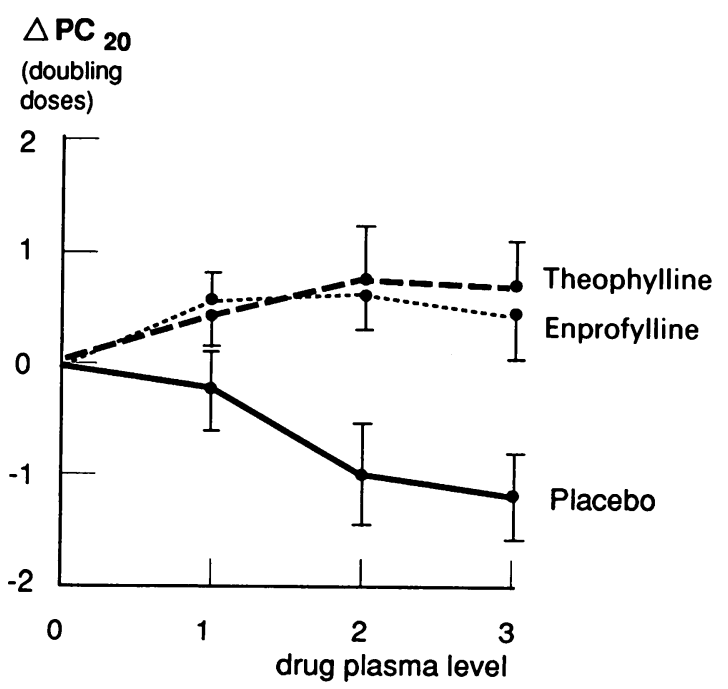

Fig 2 Effect of increasing theophylline and enprofylline plasma concentrations (by comparison with placebo) on methacholine $P C_{20}$, expressed as the change in methacholine doubling doses from baseline. The bars indicate standard errors. The drug plasma levels 1,2 , and 3 correspond to $5 \cdot 3$, $10 \cdot 2$, and $15 \cdot 0 \mathrm{mg} / \mathrm{l}$ for theophylline and $1 \cdot 2,2 \cdot 4$, and $3 \cdot 7 \mathrm{mg} / \mathrm{l}$ for enprofylline. choline ${ }^{4}$ provocation; few have looked at the effect of increasing doses of theophylline on bronchial reactivity. Cockcroft et $a \mathcal{\beta}$ found significant protection against histamine provocation only when serum theophylline concentrations were above $10 \mathrm{mg} / \mathrm{l}$. In another study ${ }^{7}$ no correlation was detected between the protective effect of theophylline on histamine challenge and theophylline plasma concentration, possibly because the comparison was between and not within subjects. In a recent report Magnussen and coworkers ${ }^{17}$ showed dose related protection of theophylline against histamine challenge and significant protection with low plasma theophylline concentrations $(6 \mathrm{mg} / \mathrm{l})$, in accordance with our results. In our study the maximum protective effect (that is, difference from placebo) was 2.0 doubling doses of methacholine for theophylline and 1.7 for enprofylline.

We conclude that although theophylline and enprofylline provide dose related protection against methacholine the effect is relatively small. Both drugs provide some protection at relatively low plasma concentrations. Increasing the plasma concentration of theophylline from $10 \mathrm{mg} / \mathrm{l}$ to $15 \mathrm{mg} / \mathrm{l}$ and of enprofylline from 2.5 to $3.7 \mathrm{mg} / \mathrm{l}$ did not lead to any appreciable further protection. The results are in accordance with recent evidence that most of the possible bronchodilator effect of theophylline is achieved at relatively low plasma concentrations. ${ }^{18} 19$

We want to thank Jeannet Kukler for her technical assistance, and Hanneka Bosma for preparing the manuscript.

\section{References}

1 Hendeles L, Weinberger $M$. Theophylline: a state of the art review. Pharmacotherapy 1983;3:2-44.

2 Mitenko PA, Ogilvie RI. Rational intravenous doses of theophylline. N Engl J Med 1973;289:600-3.

3 Cockcroft DW, Killian DN, Mellon JJH, Hargreave FE. Protective effect of drugs on histamine-induced asthma. Thorax 1977;32:429-37.

4 Koëter GH, Meurs H, Jonkman JHG, De Vries K. Protective effect of choline theophyllinate on histamine, acethylcholine, and propanolol-induced airflow obstruction. Respiration 1984;45:139-46.

5 Cartier A, Lemire I, L'Archeveque J, Ghezzo H, Martin $\mathrm{R}$, Malo JL. Theophylline partially inhibits bronchoconstriction caused by inhaled histamine in subjects with asthma. J Allergy Clin Immunol 1986;77:570-5.

6 Levene S, McKenzie SA. Protective effect of theophylline on histamine-induced bronchoconstriction in asthmatic children. Br J Clin Pharmacol 1986;21:445-9.

7 McWilliams BC, Menenokz R, Kelly WH, Howick J. Effects of theophylline on inhaled methacholine and histamine in asthmatic children. Am Rev Respir Dis 
1984;130:193-7.

8 Persson CGH, Kjellin G. Enprofylline, a principally new antiasthmatic xanthine. Acta Pharmacol Toxicol 1981; 49:313-6.

9 Lunell E, Svedmyr N, Andersson KE, Persson CGA. Effects of enprofylline, a xanthine lacking adenosine receptor antagonism, in patients with chronic obstructive lung disease. Eur J Clin Pharmacol 1982;22: 395-402.

10 Persson CGA, Erjefalt I, Edholm E, Karlsson JA, Lamm CJ. Tracheal relaxant and cardiostimulant effects of xanthines can be differentiated from diuretic and CNSstimulant actions of xanthines. Role of adenosine antagonism. Life Sci 1982;31:2673-81.

11 Kraan J, Koeter GH, v.d. Mark ThW, Sluiter HJ, de Vries $\mathrm{K}$. Changes in bronchial hyperreactivity induced by 4 weeks of treatment with antiasthmatic drugs in patients with allergic asthma. $J$ Allergy Clin Immunol 1985;76:628-36.

12 Jonkman JHG, Schoenmaker R, Greving JE, De Zeeuw RA. Rapid and selective theophylline and saliva assay by means of high pressure liquid chromatography. Pharm Weekblad (science ed) 1980;2:49-53.

13 Edholm LE, Bodenas C, Heintz L, Ogren L. Column liquid chromatography for the quantitative analysis of enprofylline in biological samples. In: Andersson KE,
Persson CGA, eds. Anti-asthma xanthines and denosine. Amsterdam: Excerpta Medica, 1985:238-42.

14 Kraan J, Borgstrom L, Koëter GH, Laseur M, De Noord $\mathrm{OE}$, Jonkman JHG. Creation of four consecutive instantaneously steady-state plasma concentration plateaus of theophylline and enprofylline by repeated infusions with exponentially decreasing delivery rates. Eur J Clin Pharmacol (in press).

15 Nie NH, Hull Ch, Jenkins JG, Steinbrecher K, Bent DH. SPSS handbook. Releases 7-9. New York: McGrawHill, 1981.

16 Cartier A, Malo JH, Bégin P, Sestier M, Martin RR. Time course of the bronchoconstriction induced by inhaled histamine and methacholine. J Appl Phys 1983; 54:821-6.

17 Magnussen H, Reuss G, Jorres R. Theophylline has a dose-related effect on the airway response to inhaled histamine and methacholine in asthmatics. Am Rev Respir Dis 1987;136:1163-7.

18 Klein JJ, Lefkowitz MS, Spector SL, Cherniack RM. Relationship between serum theophylline levels and pulmonary function before and after inhaled betaagonist in "stable" asthmatics. Am Rev Respir Dis 1983;127:413-6.

19 Fairshter RD, Busse WW. Theophylline-how much is enough? J Allergy Clin Immunol 1986;77:646-8. 